\title{
THE NUANCES OF CRIMINALITY AND VIOLENCE IN CONTEMPORARY NIGERIAN POPULAR MUSIC: IMPLICATION FOR MUSIC PRODUCTION AND ENGINEERING
}

\section{CHIJIOKE NGOBILI \& BENEDICT AGBO*}

Department of Music, Faculty of Arts, University of Nigeria, Nsukka

\begin{abstract}
This article examines and discusses how criminality, violence, and Nigerian popular music interface and interact to shape and influence the Nigerian society, politics, language expressions, and its youths since the $21^{\text {st }}$ century. The article relies on oral/written interviews, opinion polls conducted through a social media platform (Facebook), and some of the extant literature on the Nigerian popular music published on mainstream and other media. Also, six Nigerian hip-hop songs and raps by Olamide, Teni, Lil Kesh, Naira Marley, and Chinko Ekun are selected for examination based on their criminality/violence themes. An important finding is the nuanced overt and covert promotion/endorsement of crime, criminality, criminals, and violence in the textual and musical contents of the selected songs. This, in turn, opens up a further inquiry into the socio-political and sociological backgrounds, formations, and influences of some Nigerian artists as well as the implications on their youthful Nigerian audiences as well as music production and engineering. Addressing properly this ugly trend in music industry will improve music production and engineering

KEYWORDS: Nigerian popular music; Nigerian hip-hop and rap; criminality; violence; promotion/endorsement; music production
\end{abstract}

Received: Dec 08, 2020; Accepted: Dec 28, 2020; Published: Mar 30, 2021; Paper Id.: IJMPERDJUN20216

\section{INTRODUCTION}

Crime, violence, and music are largely human acts that are as old as their actors in every society. Often, crime, violence, and music take the shape, status, and state of the human agencies that produce them because they are all forms of responses from within. And as is the human person, so is the music; and as is the human person, so is the propensity for and nature of crime and violence. In other words, music is produced from a collection of conscious and unconscious experiences absorbed by the human producer over time, just as crime and violence are generated from human influences and impulses. The preceding helps to understand and place the agency of producing music, crime, and violence in several societies of the world today. Indeed, crime and violence have had to accompany music, and music, in turn, has had to accompany them. Humans are capable of generating elements of crime and violence in music as well as music in crime and violence (Johnson \& Cloonan, 2009). This is because music is a social creation, one which is a big part of a matrix of practices that reproduce a people's social life (Kahn-Harris, 2003).

In Nigeria, the social life is largely driven by popular music, and the last two decades have seemingly proven to be the peak of all times, drawing great attention from scholars and non-scholars alike. But to date, little scholarly attention has been given to the interface between criminality, violence, and Nigeria's popular music practices and how that shapes and influences the Nigerian society and its youth population in the $21^{\text {st }}$ century. 
While Christopher (2012, 2013), Onanuga and Onanuga (2020), and Eze (2020) have examined the relationship between Nigerian popular music and violence, sexuality and sexism through textual and linguistic analyses, this discourse has approached the interface between Nigerian popular music and criminality/violence from musicological, historical, sociopolitical, and iconographic perspectives.

Focusing on the trends and developments, this article examines the Nigerian popular music practices between the late $20^{\text {th }}$ and early $21^{\text {st }}$ centuries, especially as they implicate notions of criminality and violence. However, specific consideration is given to the five years between 2014 and 2019. The article also specifically focuses on Nigerian hip-hop and rap because they are the predominant genres that have so far been used to nuance criminality and violence since the inception of the $21^{\text {st }}$ century. The themes, contents, styles, language, texture, and contexts of the six selected songs, as well as the backgrounds of some of their respective artists, not only highlight the nuances of overt and covert endorsement of specified crimes and violence-related contents but also reveal the illicit socio-political trends, connivances, and networking that irrigate the 'system'. By system, we refer to the aggregation of cultural foundations, political relationships, traditional hegemony, and musical creations that work as a hierarchical body-consciously or organically —in the nuanced endorsement, promotion, and inspiration of crime, criminality, and violence among the young Nigerian population.

\section{TECHNICAL CONTENTS}

\section{Nigerian Popular Music and Popular Music Practices in Nigeria: a Brief Overview}

For immediate clarity, "Nigerian popular music" refers to the corpus of popular music genres and musical practices that are Nigerian in origin (ethnic or national) or have been domesticated/'Nigerianized' over time and which exist within Nigeria and/or the Nigerian diaspora. Examples include Fuji, Akuko n'egwu, Dadakuda, Egwu Ekpili, Nigerian highlife, Nigerian hip-hop, Nigerian rhythm and blues, Nigerian rap, Afro-beat, among others. By contrast, "popular music in Nigeria" refers to the larger and diverse corpora of all the popular music genres and practices-indigenous, foreign, and transnationalthose was formerly in active use and/or are still found active in Nigerian spaces. Examples include the aforementioned genres under the "Nigerian popular music" as well as such genres as jazz, soul, rock, rhythm and blues, salsa, worship, Ghanaian highlife, and others from across the Americas, Europe, and other parts of Africa. This distinction between the "Nigerian popular music" and "popular music in Nigeria" has been established given subsequent related concerns, such as in the understanding of the influences that inspired the evolution of certain popular practices and culture in Nigeria. Sylvanus (2018) bi-focally categorizes the entire corpus of the Nigerian popular music since the $20^{\text {th }}$ century into "glocalized" genres (those that have Euro-American appropriations) and "localized" genres (those that have of Nigerian/African origin) (pp.2-3). This study, however, explores the Nigerian popular music focusing on hip-hop and rap genres.

\section{Tracing Criminality and Violence in Nigeria's Popular Music Experience}

The earliest endorsement/promotion of themes and contents associated with criminality via officially produced popular songs in Nigeria subsisted between 1980 and 2000. This is evidenced in some highlife songs of that period whose contents and themes focused on individuals of criminal character and wealth source who were later convicted of crimes, strongly accused of crimes, or exposed publicly as criminals. An example is a song, Alusị Okuzu (Awkuzu) in the album, Nwanne Dị $N a M b a$ (released in 1995) by the İgbò highlife maestro, Oliver de Coque which lavished praises on a certain John 
Nebolisa who would later be accused of advanced fee fraud a.k.a '4-1-9' and arraigned in a tribunal court of Lagos in 1998 (Nworah, 2005).

The first indigenous Nigerian hip-hop song that glamorized Internet fraud was Mobolowowon by D'Banj (Daniel Oyebanjo). It was produced/released as at 2004 (Lazarus, 2018; Tayo, 2018). I Go Chop Your Dollar by Nkem Owoh which was released in 2005 followed it. From available records, it appeared that the Internet fraud theme featured little until around 2008 when it exploded with a list of well-known songs that projected it from 2008-2017 numbering over 12 songs (see Lazarus, 2018).

\section{Examination of Selected Nigerian Hip-Hop Songs and Raps}

As have been mentioned earlier, six songs were specifically selected to be examined in this article. The selected songs include: 1. Story for the Gods (Olamide, 2014), 2. Case (Teni, 2018), 3. Logo Benz (Lil Kesh, 2018), 4. Japa (Naira Marley, 2018), 5. Am I a Yahoo Boy (Naira Marley, 2019) and 6. Able God (Chinko Ekun, 2018)

The selections were based on the diversity of the coverage of criminality/violence-related themes which include: glamorization/promotion/spiritualization of cybercrime/Internet fraud (a.k.a yahoo-yahoo) as well as related crimes; money rituals and the invasion of female privacies for their facilitation; open recognition/promotion of individuals who are and have been publicly associated with the deaths of persons, intimidation and street violence; subtle encouragement of female rape as well as the shaming/trivialization of rape victims; evasion of justice and its encouragement. The critical discourse analyses of the songs follow no particular order of the themes.

\section{Story for the Gods}

This song has been criticized by many Nigerians both on the social and mainstream media for its overt encouragement of rape and scorning of date rape victims. Mainstream online media, Sahara Reporters has published a strongly-written opinion piece by Ohwojeheri (2014) that criticized the song and offered deeper insights on the etymology of certain slangs in its lyrics. To date, references are still made to the song whenever the obscenity in modern Nigerian popular music is discussed. We have to focus on the offensive lyrical lines and then examine them analytically based on meanings and representations. The song begins with [in Yoruba language]:

O ti mu dogoyaro [I have taken dogoyaro...Like monkey tail]

Ba mi wey claro [Help me wrap claro]

I want to do sina today [I want to have sex today] (Olamide Baddosneh, 2014)

These introductory lines, in summary, say that he (Olamide or any imagined male character) has taken weed substances like "monkey tail" and still desires to consume more. The direct impression from the above lines is an endorsement of excessive intake of intoxicants which catalyze sexual excesses, social misconducts, and health hazards. And, the video of the music overtly nuanced the impression as some young ladies are seen exhaling thick wisps of smoke from their nostrils and mouths while some others indulged in wild sexual gestures. The lines that follow go thus: "she says she cannot wait o, she says it's getting late o, she says she wants to faint oo. Ha! Story for the Gods. Now she says 'mo ro go' ['I'm in trouble']. O ti kan mi lapa oo ('he has broken my hand o'). O ti kan mi leyin o ['he has broken my back'] ...story for the gods" (Olamide Baddosneh, 2014, 0:31). 
Olamide, in the preceding lines, scorns the rape victim by mimicking her anguish in her exact words. He goes further to trifle it by describing it as "story for the gods" - a Nigerian street phrase for 'a stupid tale', which validates shaming rape victims and violence towards women. The rap's message reinforces apathy to the plight of the rape victim by telling her to invite more women (Folake, Atinuke, and Dupe) so that he (Olamide) and his friends can share them while "flexing"- another Nigerian street word with undertones of sexual adventurism. Olamide mentions that they (the women) meet him in his 'Benz' - a symbolic word used by Nigerians to associate Internet fraudsters (Yahoo boys) who are reputed for owning mostly Mercedes Benz cars (Benzers). The 'Benz' car logo would later be associated with Olamide (in 2018) in a song he was featured and which we shall encounter in this discourse. Finally, misogyny and violence are nuanced by rudely ordering the female character around such as saying to her [translated to English]: "if you feel pain hold the pain", and "come on stand up, don't sit on the chair" (Olamide Baddosneh, 2014, 2:00-2:21).

Beyond the texts, there are other nuances of violence and criminality via musical and lingual mechanisms. For example, why does Olamide employ bilingualism/ trilingualism in some of his songs? Why does he prefer to deliver the less toxic lines in English or Pidgin English and delegate his native Yoruba language to carry the weight of the violence/criminality content? Perceivably, the aim is to encode the toxicity for the unsuspecting non-Yoruba-speaking audiences. Musically, Olamide, aside from his natural nasal singing, often deploys a significantly coarse and forceful voice mixed with nasal texture when he is rapping a violence/crime-related content. Some have called the vocal phenomenon "street voice" - a reflection of the aggressive show of force and intimidation tendencies typical of street gangsters and motor-park touts (locally called Agbero-Yoruba word for "tout"). These Agberos are found mostly in the south of Nigeria, in such cities as Lagos (southwest) and Onitsha (southeast). Olamide has been famously hailed the "king of the streets" and has a 2013 song entitled Voice of the Street, lending credence to his stature and ambassadorship of the street culture which includes the guttural singing style. This guttural "street voice" feature and mechanism can be observed in other Olamide's songs/raps that nuanced street, criminality, and violence.

\section{Case}

This song is themed on romance. But criminality is covertly nuanced in it following a small but important portion of the lyrics which goes thus:

I go go Oshodi for your Case,

I go slap agbero for your Case

I go call M.C Oluomo, I go report all of them (Teni Entertainment, 2018, 1:13)

The contending expressions/names here that implicated or nuanced criminality/violence are Oshodi and M.C Oluomo. Oshodi is officially a local government area under the Ikeja Division of Lagos State, Nigeria, with a 2016 projected population of 866,300 residents (City Population, 2016). Owing to the reputation it has had over the decades for crime and violence, Oshodi has become synonymous with street thuggery, theft, and the infestation of Agberos. This concentration of criminal activities and criminally-minded youths in Oshodi has made the area evolve into a power center and capital of motor-park-related politics in Lagos city under the governmental agency of the National Union of Road Transport Workers (NURTW), Lagos State chapter. The activities happening under this agency - criminal and otherwise have become so sophisticated that they generate substantial revenue for the government of Lagos and also attract highpowered politics which includes desperate jostling for the agency's leadership and finance management positions 
(Ehbomele, 2011). When Teni, in this song, refers to “Oshodi” as a place she would go for her lover's Case, it implies obtaining powerful support from the criminal and violent gangs that rule the area. By doing so, she promotes this area of nefarious activities as a place of getting instant justice or edge over a rival. To strengthen the nuance of promoting an area of crime, she goes on to say "I go call M.C Oluomo”, recognizing a notorious name in Lagos that has been associated with leading factions that perpetuate crime, intimidation, harassment and even murder of people (Ugbodaga, 2015a, 2015b). As at the time of the release of Case, M.C. Oluomo (Musiliu Ayinde Akinsanya) has become a chieftain and the chairman of the NURTW in Lagos, making him the biggest force in the Oshodi power circles and other similar districts in Lagos. However, a compelling question is: why does Teni find it important to honor such a character in her song? In an extensive interview granted us, Bimbo Morayo who has lived in the areas of Lagos where the street thugs operate and has associated with them gives a revealing insight pointing to the security assurance they provide whenever musicians want to tour their territories. Morayo cites an instance of how Pasuma (a Yoruba popular musician) began his carrier in the 1990s at Sunny Ade (an older musician)'s office in Jibowu, Lagos, but was roundly trammelled by Jayproun (a popular Agbero leader) who got him wounded for employing another thug (a huge bouncer) for self-protection while appearing for a performance in his territory. Shina Peters (another Yoruba musician) is also reported to have had same experience at Akerele Extension, Surulere in 1999. Morayo concludes that "most of these artists have, in one way or the other, got protection from MCOluomo; even the Yoruba film actors do the same". ${ }^{1}$

Notably in 2019, Olamide released a new song titled Oil \& Gas where he hailed and recognized a litany of rich and influential men in Lagos city. A line in the lyrics goes thus (in Yoruba language): “MC Musiliu, eyin lenu daku” [“MC Musiliu, you have mouth"]. That was Olamide recognizing MC Oluomo as a powerful force in Lagos city. For Teni and Olamide to recognize a notorious character like MC Oluomo in their respective songs tells a lot about MC Oluomo's association with contemporary popular artistes in Lagos as well as his influence on them. That said; Morayo's responses to our interrogations expose a complex network of power dynamics, political/financial interests, and social relations that implicates a replication of and annexation to the Yoruba traditional hierarchical systems/leadership structure existing between the artists and street thugs. This network can be summarised thus: the street thugs/Agberos (who dominate the NURTW, Lagos chapter) and their counterparts who focus on dominating the streets derive their powers and authority from the Lagos State politicians in power to operate legally in the generation of revenues for the government. By extension and with the State presumably oblivious of it, they intimidate and harass citizens for their own financial and political interests. They also derive powers from the traditional rulers of the areas they operate in, which give them the impetus to illegally extort people and entrench a dominant control of the territory and activities happening within as the police officers feign ignorance. Such activities include musical concerts organized by Nigerian secular and gospel artists, carnivals, film shootings, marketing activities, elections, among others. The music artists, filmmakers, marketers, and other event organizers are caught up in a hierarchical power web where they are compelled to "settle" the thugs and show them direct/indirect recognition, unaware of their loyalty to a hegemonic network of legal and illegal establishments and interests. This complex network, tracking its roots, interactions and character represents an extended hegemony.

\section{Extended Hegemony}

'Extended hegemony' is a term we coined to refer to the extension of a small group's hegemonic dominance over a people or group of persons to another group, often by force and compulsion and for a reasonably long time. Within this context, it

${ }^{1}$ personal communication, July 15, 2019 
represents a perpetuated and extended dominance of southwest Nigeria's traditional and modern political hierarchies in which young Nigerians (often males from the southwest) with criminal tendencies/records, as well as street thugs, get to share some legitimate powers of the local society. These youths, in turn, use these powers ruthlessly or overtly to influence and control the music industry of Nigeria and other sectors of entertainment in their chosen ways. It is important to note that what is presently the corpus of contemporary popular music culture and practices of Nigeria today has been and is continually generated mainly from two major ethnicities of southern Nigeria, namely the Yoruba (in the southwest) and Igbo (in the southeast) as well as several ethnic minorities such as the Ijaw, Ibibio, Annang, Kalabari, among others (within the Niger Delta area). Northern Nigeria, on the other hand, is a less active participant in the contemporary Nigerian popular music industry partly owing to the predominance of the Arab-Muslim influences among its population as against the largely Christian south with Euro-American influences. Lagos (in the southwest) is the cultural and financial capital of Nigeria where over $90 \%$ of Nigeria's popular music are produced and circulated from. Also, the musicians are domiciled and thriving there. The geographical edge of Lagos as Nigeria's cultural capital has naturally made Yoruba cultural resources a major cynosure in the discourse of Nigeria's popular music practices since the $21^{\text {st }}$ century. It has also bred, in Morayo's words, "a long tradition of the hegemony of criminals [unlike] in other regions of Nigeria", showing regional peculiarity.

Tracing the roots of this hegemonic system, the traditional Yoruba hierarchical political structure is implicated where there are unflinching loyalty and subservience to an Ooni to Alaafin to Oba to Aare to Baale, in the order of their dominion scales. Morayo (2019) adds that the hegemony is traceable to the pre-colonial system of the Yoruba which still exists side by side with the modern political arrangement of Nigeria as attested by other Yoruba scholars ${ }^{3}$. In comparing the major ethnicities in Nigeria and how their traditional systems differ and influence modern pursuits, Achebe (2012) affirms thus on the influential Yoruba traditional political hierarchy: "Unlike the Hausa/Fulani, he [Igbo] was unhindered by a wary religion and unlike the Yoruba unhampered by “traditional hierarchies”” (p.74).

Beyond the roots of Yoruba traditional hierarchies, Morayo (personal communication, July, 2019) exhaustively submits that the modern evolution of the hegemonic persistence began before Nigeria's return to civilian rule in 1999 when mafia thugs reigned in Lagos. However, the then military administrator of Lagos tried using military force to dislodge the thugs but failed. He cited instances of how Blue boy, a leader of one of the gangs featured as a bodyguard in one of Evi Edna Ogholi (older female Nigerian artist)'s songs in the early 1990s and how most cases of rape, thefts, and shop attacks in the area were brought to him for resolution. In addition, he mentioned that Bola Tinubu (Lagos State governor 19992007) knew about the thugs and quickly seized the opportunity to use them for elections and other jobs when he eventually became Lagos State governor in 1999. Thus, over the years, they grew into a hegemonic force. "Most of them", he said "became millionaires just from this illegal and criminal consistency. I have associated with both the artists and the thugs. The thugs love it when you recognize/honor them before doing your things".

This hegemonic exploitation and perpetuation show that the Lagos State Government, since 1999, has been giving direct and indirect backing to the street thugs/motor park touts (Agberos) through either a governor in power or one who

\footnotetext{
${ }^{2}$ Personal communication, July, 2019

${ }^{3}$ For more insights on Yorùbá traditional and modern political hierarchies, see T. Falola \& A. Genova. (Eds) (2006). Yorùbá identity and power politics. US: University of Rochester.
} 
has vacated office. Bola Tinubu is again named as an enabler of the thugs with the notorious MC Oluomo described as "his chief thug". ${ }^{4}$

On the hegemony, Morayo (personal communication, July, 2019) concludes that "Any musician, either local or international, must know how to relate with and settle the local thugs in our dear southwest. All roads/lands in Lagos are connected to thugs, cartels/mafias..."

From the discourse so far, it can be seen that a hegemonic chain of interaction between three groups extends its influence to determine the atmosphere needed for a musician's performance in most parts of Lagos State where substantial money is generated. This, in turn, determines or influences the content of the musician's creative work as well as the perception and consumption of the audience. It can also be seen, from the whole data afore that this network of interactive influences has lasted for nearly three decades in Lagos (since the early 1990s), qualifying it as a truly "extended hegemony" and aptly nuanced in Teni's song.

\section{Logo Benz: Tune and Text Analysis}

The musical texture of this song is moderately light and there are not too many instruments competing with each other (see figure 1 below).

\section{fast $d=120 \quad$ LOGO BENZ}

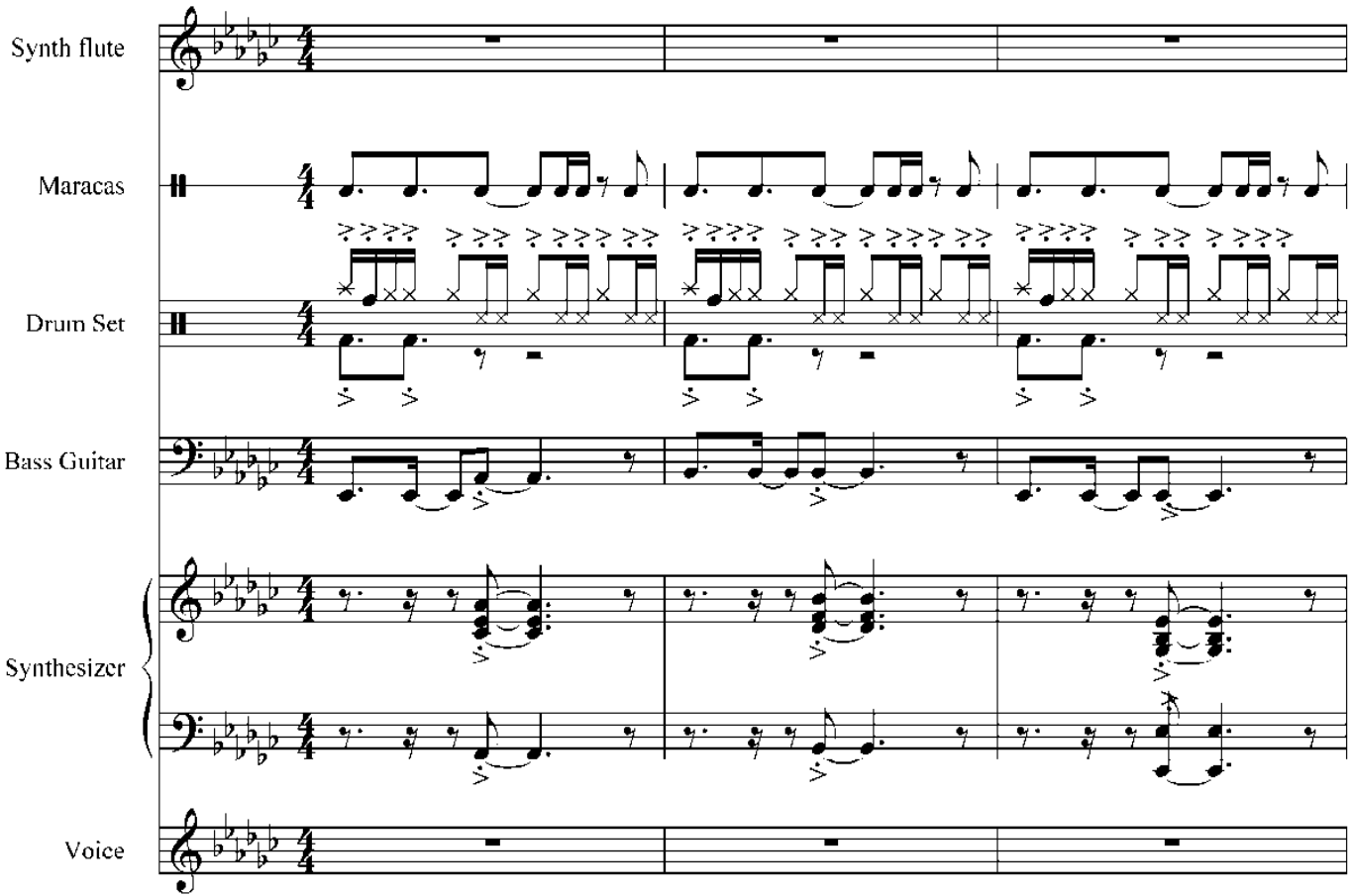

\footnotetext{
${ }^{4}$ Former governor of Lagos State, Bola Tinubu, earlier in 2019, was accused of plotting to install his son as the next governor of Lagos State and the notorious MC Oluomo identified as "his chief thug", http://saharareporters.com/2019/02/28/tinubu-has-positioned-his-son-become-lagos-governor-2023
} 


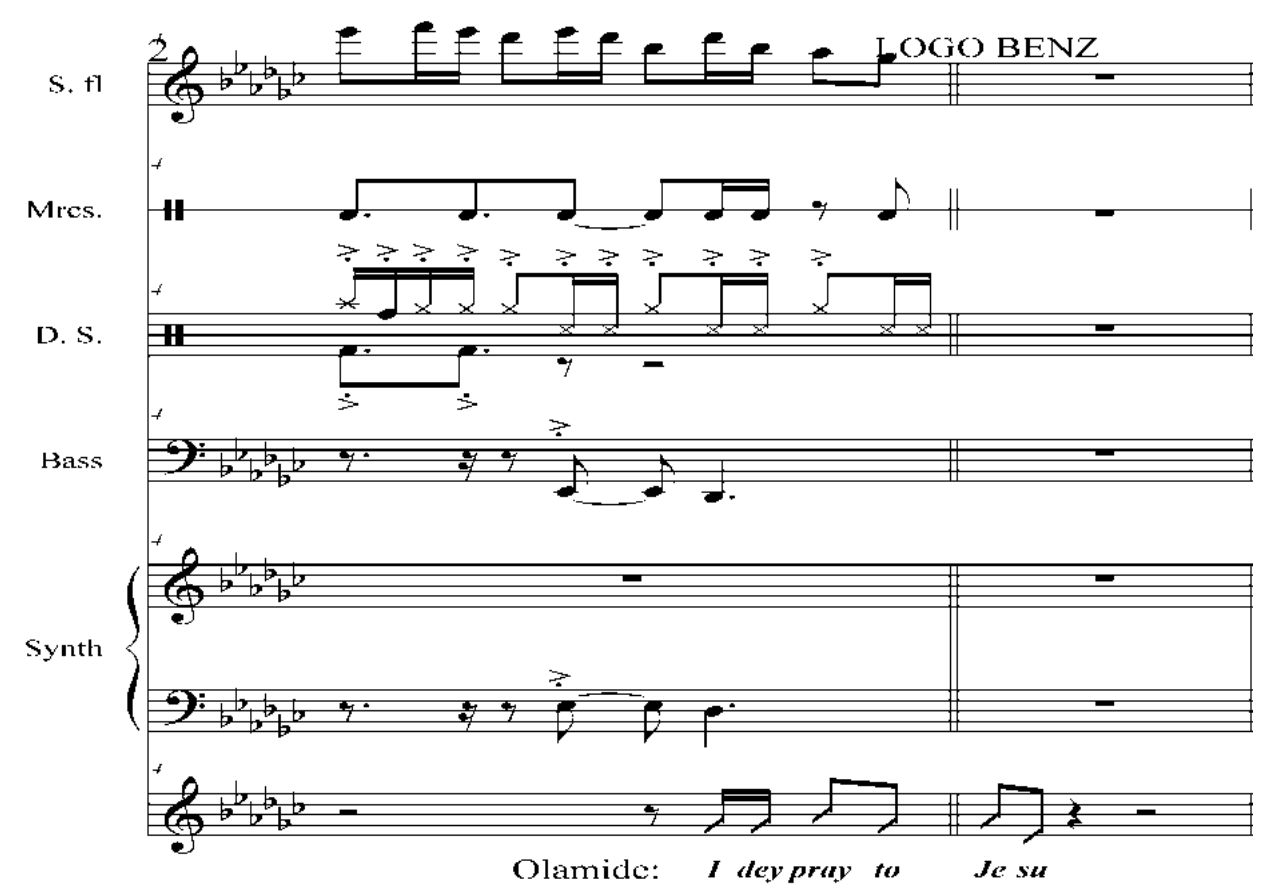

Figure 1: Expository Schematic of Lil Kesh's 'Logo Benz'. Scored by the Corresponding Author

The instruments include a synthesizer keyboard, a bass guitar and a synthesizer flute as the principal melodic/harmonic instruments while the rhythmic ones are synthesized drum set and a dry-sounding timeline marker (maracas). The entire rhythmic layout of the song is fast, busy and forceful with the kick drum hitting hard on the first beat of each bar (see figure 2), thus, inundating the senses with a populist accentuation of the song which is quickly expressed in nodding, shimmying or even dancing before the voice begins to proclaim the message. Onwuegbuna (2016) asserts that the Nigerian popular music rhythm is "functionally designed to excite motor stimulation for bodily responses". Incidentally, most Nigerian hip-hop songs that nuance criminality and ill messages barely give the listener any chances or sense of drama by varying the entries of the rhythmic layers as it is quick to "excite motor stimulation" (p.119). This practice disarms moral inclinations and compels the listener's acceptance early enough. Chinweuba Odo (DjRobitonzz), a Nigerian music producer and disc jockey based in southeast Nigeria admits that it is indeed deliberate:

Once you set the metronome at 125 BPM and above, the tempo is increased and the aim is to make a 'Party Jamz' and get people to forget about everything. So, the artists are ready to say everything they want to say in the song. They do not say them for everyone to understand. The real messages are for a target audience to grab and in a particular mood [of excitement]. But while this happens, the other unsuspecting listeners are soaking up the messages sub-consciously and normalizing them in their heads. The vulnerable young men at the party arenas where such songs are played become more motivated to practice what the songs preach when they see Yahoo boys throwing lots of money around at the party. ${ }^{5}$

However, the rhythmic layers of such songs are intermittently suspended within the singing for about two seconds to drive in a sensitive part of the message, such as when, in Logo Benz, there was a short rest for the voice to emphasize "fun won jo" ["pull the pant for them"]—an expression we shall soon encounter its implication.

\footnotetext{
${ }^{5}$ Personal communication, May 9, 2020.
} 
Harmonically, the song's layout is tender and beguiling. The chords consistently progress from IV-V $-\mathrm{I}(\mathrm{Ab}$ min - $\mathrm{Bb} \min -\mathrm{Eb} \min )$ in the key of $\mathrm{Eb}$ minor throughout the three-minutes-and-fifty-one-seconds (3:51), ambushing the listener's senses with the characteristic meekness and sobriety of a minor mode. The synthesized keyboard does not come at the strong beats but syncopates on each bar's second (weak) beat while the bass guitar gently murmurs at the background keeping to the chord progression. The Synth flute, with its scale lines, interjects at the cadences and serves as a bridge between the refrains and verses while embellishing the music nicely to conceal its dark messages.

Vocally, the song is entirely an exercise in speech-singing (see example in figure 2). Aside the raps by Lil Kesh, the vocals mediate between singing and speaking while keeping to the rhythm. The implication is that the nuanced messages are clearer and more forceful, enabling their overt delivery and normalization in the process. The refrain "pata $n i$ Logo Benz [pant is the logo for Benz]; Afe wa benz [we want to drive Benz]" is reinforced with more voices of males emphasizing in unison their desire for the Benz. Taken together, the vocalizations can be summed in one word-defiance, as the rhythm is deliberately forceful and the harmony sensuously misleading. These characteristics essentially facilitate the communication of the nuances embedded in the tune.

Turning to the textual examination of the song, it has to be recalled that within 24 hours of its release two years ago, Logo Benz was greeted with fierce criticisms from Nigerians on various media platforms. The torrent of social media posts that called out the song as highly immoral was intense. It appeared that no criminality-themed song outdid it in the overt nuance in the last five years (Aworinde, 2018). The reactions drew more attention to the song earning it more downloads and reviews. A greater part of the song overtly nuanced criminality and sexual abuse of women. But the lyrics are examined under the following terms to decongest and simplify the underlying meanings and nuances:

\section{Symbolic Simulation}

This is a term we coined to explain the iconographic nuances of criminality and violence covertly embedded in the song, Logo Benz. The nuances in question are actually in the song's cover design.
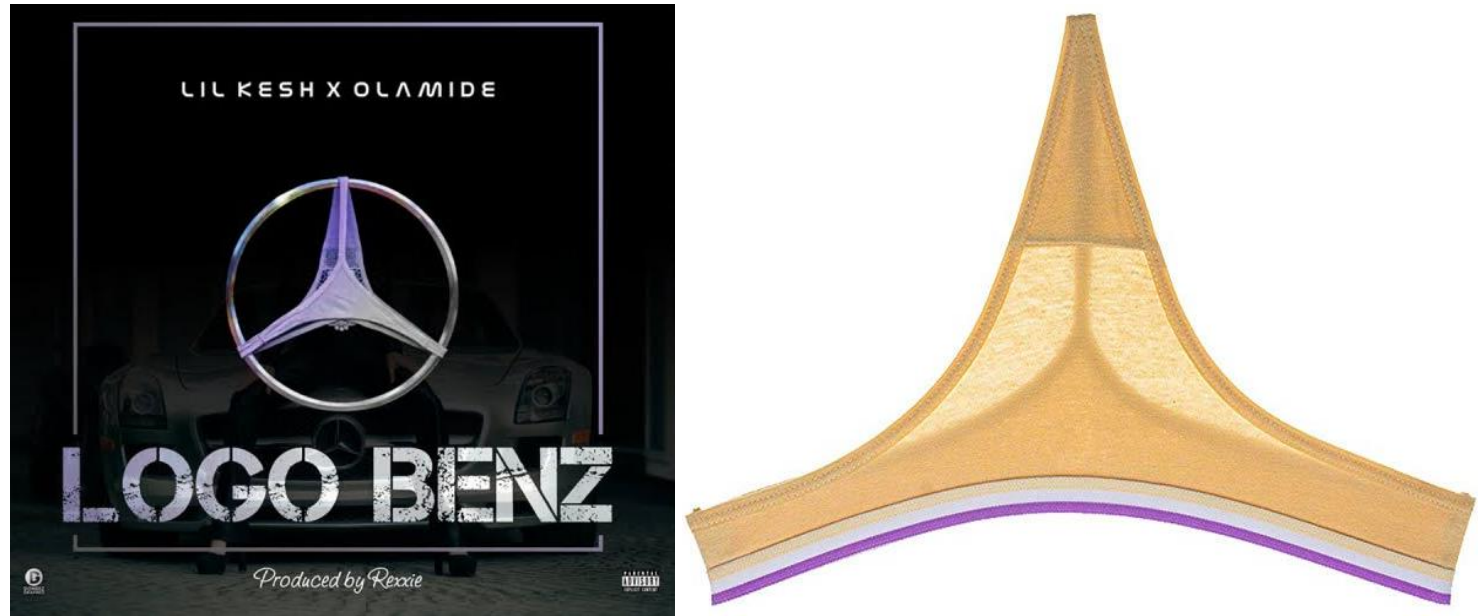

Figure 3: Cover Design for Logo Benz Song. Used with Permission Figure 4: A ladies' G-String Underwear/Pant Reversely Flipped at an angle of $180^{\circ}$. Source: Google 


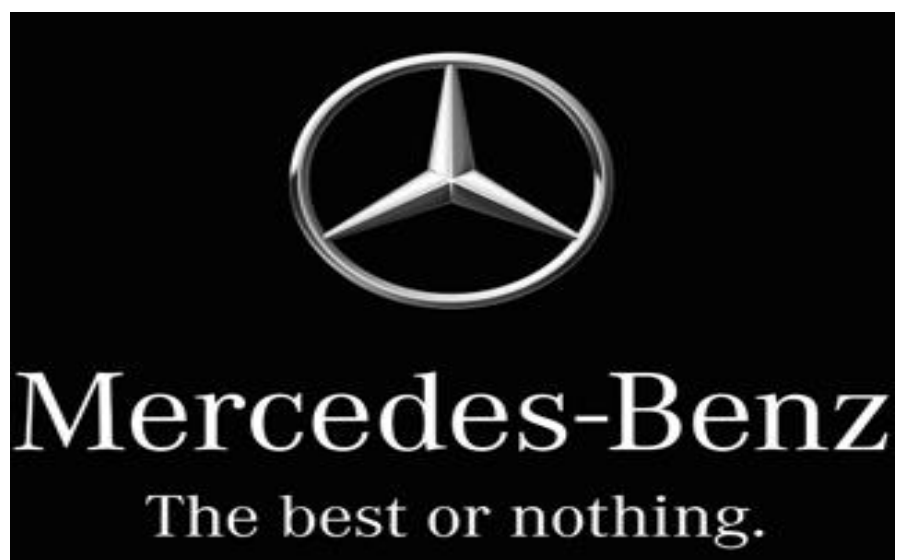

Figure 5: Official and Real Mercedes Benz logo. Used with Permission

To begin with, these images afore are interconnected in their expressions of nuanced criminality and violence. Figure 3 is the official cover design for the song, Logo Benz. It contains a falsely-represented Mercedes Benz logo with its three-point star simulated with a reversely flipped ladies' G-string pant (see figure 4). Furthermore, in the blurred background of figure 3, there is a skinny young lady in shiny tight trousers sitting at the middle edge of a white Mercedes Benz's hood. Her legs are spread apart flanking the embossed Mercedes Benz logo on the car's grilles. Figure 5 is the real Mercedes Benz logo with its lingo "the best or nothing" - the very motivation behind the choice of Mercedes Benz cars by many Nigeria's Internet fraudsters. To decipher why Mercedes Benz seems to be the car brand choice of most Nigerian Internet fraudsters (a.k.a Yahoo Boys), we assembled and interrogated 10 undergraduate students of the Faculty of Arts, University of Nigeria, Nsukka who are mostly based in Lagos and elsewhere in Nigeria but confessed being conversant with the lifestyles and operations of Yahoo boys. $100 \%$ of them responded that: It's all about class. Many people in the world regard Mercedes Benz as the best automobile brand. So, when a Yahoo boy hits money and buys a Benz, for him, he has automatically scaled to the top in the social classing. That way, Benz became symbolically synonymous with Yahoo boys in Nigeria within the last ten years or so. Some of them drive other brands, but Benz is the ultimate.

The students' answer appears quite convincing because the cost of modern Mercedes Benz cars in Nigeria outranks other popular brands like Toyota. So, the Yahoo boys simply want to be seen driving one of the most expensive, if not the most expensive, car brands. Also, some Nigerian security agents have absorbed the rumour that young men who drive modern Benz cars are all Yahoo boys, hence their harassment and arrests of any young man they see wheeling a posh Mercedes car including decent and law-abiding ones ${ }^{6}$.

The next issues are: why is there a ladies' G-string underwear and what is it doing in the image simulation? Also, why is there a young lady in the middle background of the simulated image? To unpack this phenomenon, one needs to appreciate that money ritual (enrichment through diabolic means that include human or human-related sacrifices) is a reality mostly in the south of Nigeria. Often, several cases of money rituals have been reported and are still being reported in the Nigerian news media up till the present. Specifically, Internet fraud (Yahoo-yahoo) in Nigeria has a more advanced or complex version popularly known as "Yahoo Plus". Yahoo Plus is not only a euphemism for engaging in Internet fraud with the aid of charms made from shady rituals for quicker results but the contemporary expression for "money ritual with human parts or blood" (Folarin, 2019). At that level of moral depravity, certain strange requirements are made of the

${ }^{6}$ A particular case, in 2019, is reported of a Nigerian police officer harassing a Nigerian footballer because he drove a
Mercedes Benz car despite confirming his identity and other requirements: allafrica.com/stories/201908280568.html. 
Yahoo Plus boys by their clients and they include: female underwear (ones that have been worn and are still in use), human parts of females and children (such as breasts, heads, internal organs, among others), used menstrual pads and baby diapers, and so on. (Genius TV Radio, 2018; Ige, 2019). The foregoing compels one to see that the main victim at the center of the Yahoo Plus syndrome is the young female Nigerian whose body parts or underwear are in high demand by the criminals.

The stealing of female underwear and its deployment for money rituals by Yahoo Plus boys, incidentally, became very rampant and a major Nigerian news item in 2018. Tellingly, the song in context (Logo Benz) which glamorized and normalized this trend was also produced in 2018. The symbolic simulation of the Mercedes Benz logo in its cover design (figure 3) covertly nuances an iconographic adoration and promotion of Yahoo Plus abetted by dispossessing Nigerian females of their underwear and abusing them physically and metaphysically in the process. In this way, a criminal practice is condensed into a logo, euphemized and engraved onto vulnerable young Nigerian minds.

On the other hand, the nuanced physical violence against young women is reinforced in such lines as "Bo Pata là fun won jo [pull down the pant for them]" (KeshVOVO, 2018). It lends credence to the news reports of Nigerian women who have been forced at gunpoint by suspected Yahoo boys to pull off and hand over their underwear (pants) to them ${ }^{7}$. Also hinting nuanced violence towards young women in the song is the line: "Ka le gbo mo lo, ka le gbo mo scatter [so we can go with the babes and scatter them]" (KeshVOVO, 2018, 1:06). It is unclear what the action "scatter" fully represents about the young women but it implies sexual violence as well as offering up the women, in their unconscious states, for money rituals. The Nigerian news media, mainstream and social, is awash with reports of the disappearance of young undergraduate females who unwarily followed Yahoo boys to/from a party as well as the discovery of dead bodies of young ladies in hotel rooms with some missing body parts linked to Yahoo boys too (Adeniyi, 2020).

Finally, in the song, Logo Benz, the lead vocalist gave an example that may be considered real-life: "Ah! get this lери [I know a lady] ...If you gbope she go sope [if you give her money, she would give you sex] ...She runs away if you're not able... Nedu carry her pant and he bought a Benz. Se lo ra CLK, o ra GLK [he bought CLK, and bought GLK]" (KeshVOVO, 2018, 2:06). The nuance here is of abusing a female who does not yield to sex without being sufficiently compensated with money. To teach her a lesson in revenge, her underwear is taken by force. In summary, her underwear is used by a Yahoo boy for money ritual which enables the purchase of two Mercedes Benz brands: GLK and CLK-a reminder of the Yahoo boys' symbolic attachment to Mercedes Benz cars. However, no one knows or says what finally became of the young lady whose underwear/pant facilitated the new cars.

\section{Japa}

The artist of this song, Naira Marley happens to be the most notorious of all the Nigerian hip-hop musicians as at 2019 endorsing crime, violence, and public display of offensive behaviours. Of a persona that compels curiosity, Naira Marley announces himself in the negative and has earned the highest number of criminal charges among other Nigerian artistes both in Nigeria and the UK as well as the most publicized arrest (Augoye; Sahara Reporters; Akinyoade, 2019). Indeed, he is the founder of "Marlianism" (our coinage), following his numerous cult-like fandom and followers who announce

\footnotetext{
${ }^{7}$ The news reports from several mainstream Nigerian news sites include but not limited to the following: https://www.sunnewsonline.com/pants-for-ritual-yahoo-plus-boys-rob-girls-of-their-undies-at-gunpoint/; https://punchng.com/fear-of-yahoo-boys-has-made-us-stop-wearing-pants-women-in-delta-students-communities/; https://thenationonlineng.net/pant-life-2/
} 
themselves as "Marlians" and who include youths and teenagers in secondary schools. These Marlians are said to be of "a rambunctious presence everywhere he [Naira Marley] performs. They revel in being 'outsiders', and as a trademark, they are disrespectful of rules and agents of law enforcement" (Olugbile, 2020). Marley's nuancing style of criminality and violence is eclectic because he has no specific focus but varied focuses which seem to enlarge his notoriety. His songs are replete with nuances of theft, unlawfulness, obstruction/resistance of justice, ridicule of law enforcers, exposure of oneself to the risk of police gunshots, smoking intoxicants, Internet fraud (Yahoo-yahoo), gangster, prison, street, and open male masturbation. The song in context-Japa-is laced with some of the aforementioned nuances even as it generally encourages the disregard of law enforcers:

No popo [police] at my back...and I ain't gon [I am not going to] stop

Owo tollgate yen mi o ni le san [I won't pay the tollgate fee].

I'm on bed, I'm sorry

Mi o ni le looo [I won't pay]

I'm on the run o, catch me if you can

Japa japa, japa lo London [Run, run to London]

[slang] Japa japa ja wo Canada [Run, run to Canada] (Naira Marley, 2019).

As could be gleaned, these lines nuance endorsement of unlawfulness and obstruction/resistance of justice. Furthermore, Marley encourages excessive smoking of intoxicants such as ganja irrespective of its highly cancer-causing potential. The following lines implicate it: "Mo fe gun ganja [I want to smoke ganja] ...Oloun maa je a ro ogun cancer [God forbid cancer]" (Naira Marley, 2019, 1:14). Another line implicates a nuance of insolence in which a naive teenage male, for example, is encouraged to carelessly expose himself to being shot dead by the police in an effort to appear resistant/inapprehensible: "If you want to fire [shoot] me, fire make I jabo [fall]...I ain't [I am not] going to that station" (Naira Marley, 2019, 2:37).

\section{Am I a Yahoo Boy?}

This is another song by Naira Marley featuring Zlatan Ibile which was released shortly before the two musicians were arrested and detained for alleged financial fraud by Nigeria's Economic and Financial Crimes Commission, EFCC (Odunsi, 2019). Naira and Zlatan's music, including this one, have been categorized under the grime genre ${ }^{8}$ of popular music in Nigeria (Pierre, 2019) because of their heavy street contents. In the song, Naira Marley asks a rhetorical question that bears a tinge of scorn ("Am I a Yahoo boy?"), perhaps in response to accusers who warn/threaten to call SARS on him based on Internet fraud suspicion. SARS is an acronym for "Special Anti-Robbery Squad" which is a special arm of Nigeria's Police Force. Subtle ridicule of the SARS in the song is nuanced with "Sars t'emi mo is Sarz on the beat [the only Sars I know is 'Sarz on the Beat']" (Naira Marley, 2019, 0:25), in which recognition is accorded a Lagos-based disc jockey called Sarz on the Beat, through word rhyme manipulation [Sars/Sarz] while SARS is snubbed. In reinforcing the scorn and hinting the validity of Internet fraud allegation, Zlatan follows up with these lines: "Oya Yahoo Yahoo [Alright

\footnotetext{
${ }^{8}$ Grime is a genre of electronic popular music which started out in the United Kingdom (UK) in the early $21^{\text {st }}$ century.
} 
Yahoo Yahoo] ...K'oloun ma je ka Damu [God shouldn't let us be troubled] ...Maga to Sanwo mi se [as long as the Maga is paying me] ...Karin wa ko ma daru ibile [our relationship won’t be scattered]" (in Naira Marley, 2019, 1:06).

Maga (alternative: Mugu) is Nigeria's local word for an Internet fraud victim often used in derision of the defrauded. From the foregoing, it could be seen that Naira Marley denied being an Internet fraudster on the surface but agrees he is a regular beneficiary of Internet fraud, thus creating a paradoxical nuance of denial and acceptance of being a cyber-criminal at once.

\section{Able God}

Generally, this song paints a picture of the processes - (the logging into a laptop computer, the long ambush on a victim without shutting down the computer, the tension, the invocation of spirit forces for success, the crediting of bank account, and the changing of foreign currency to Nigerian currency) - that lead up to the celebratory mood of Internet fraudsters after a successful fraud. The celebratory mood is nuanced in the following lines of the song's lyrics:

"No more insufficient funds (nuancing the crediting of the bank account)

A ti sise [We have worked]

A ti gbope [We have received pay]

Aboki ti se dollar [Aboki has changed the dollar]" (Chinko Ekun, 2018, 0:40) (nuancing the conversion of the foreign currency to Nigerian currency by a Hausa/Fulani mobile Bureau de change agent who is often referred to as 'Aboki').

An important point to note here is that the song nuanced a 'spiritualized' notion of cyber-criminality with the music video shot in a church where the artists are seen praying to God. The following entry and refrain lines from the lyrics give the clue:

"Angeli t'on pin ire [Angel that is sharing blessings] - (nuancing the tension/waiting/invocation of spirit forces for aid)

Jor ma lo sun [please, do not sleep]

So, able God ... Shower your blessings...We want this money

A fe gun Bentley [We want to drive Bentley]." (Chinko Ekun, 2018, 0:5)

The notion from the lines stated afore is that Yahoo boys also rely on religious prayers and faith for success at defrauding people, even if for public show. This phenomenon is what we have chosen to term the spiritualization of criminality in Nigerian popular music.

\section{Spiritualization of Criminality in Contemporary Nigerian Popular Music}

Spiritualization of criminality is the infusion or association of spiritual meanings and leanings to crimes, criminals, and criminal tendencies. Within the context of this discourse, the spiritualization of criminality in Nigerian popular music refers to associating crimes and nuances of criminality to the Christian God, Muslim Allah, or other religious forces. Modern Nigeria is perceived as a deeply religious nation, and problematically so because this deep religiosity has always assumed extremist forms and notions which have led to devastating religious conflicts. For this reason, according to Falola 
(1998, p.1), "Nigeria is a major African theater of religious violence and aggression" whose deep religiosity, in extreme assumptions, has also enabled the generation of bitterly divisive politics and Christian denominational (Catholic, Anglican, Pentecostal) squabbles that have led to the proliferation of churches and a disturbing explosion of public praying and other religious activities. The Pew Research Centre in the United States has recently ranked Nigeria $82 \%$ among the world's most prayerful nations as "95\% (of Nigerians) say they pray daily" (Marshall, 2018; Udodiong, 2019). Socio-politically, religious activities and religiosity in Nigeria have united to form a shield, neutralizer, and diversionary mechanism for inept governance, persistent corruption, and large-scale criminalities. Consequently, corrupt politicians and public office holders who stole from the patrimony to enrich themselves are quick to tie their "successes" to prayers and God's blessings. Fraudsters, thieves, and drug traffickers also find solace and shield in the churches they attend and patronize. Nigeria's former president Olusegun Obasanjo was reported to have indicted the Nigerian churches for abetting financial crimes and corruption as they [Nigerian churches] "not only celebrate but venerate those whose sources of wealth are questionable, they accept gifts (offering) from just anybody without asking questions. This gives the impression that anything is acceptable in the house of God" (Ezeamalu, 2017). In turn, this phenomenon influences the larger Nigerian society as questionable contents are tied to/with religious leanings to neutralize their offensiveness. The theft of someone else's hard-earned money using the Internet is trivialized to appear legitimate as the Christian God is beckoned with "shower your blessings" in the contextual song-Able God. This spiritualization of crime in Nigerian hip-hop music is also nuanced in one of the songs earlier examined - Logo Benz. The Logo Benz's lines of the nuance are as follow: "I dey pray to Jesu [I am praying to Jesus]. I dey pray to Allah [I am praying to Allah]. Ko wo wole [let money enter]. If money no enter I go do blood money [If money does not come, I will engage in money ritual]" (KeshVOVO, 2018, 1:26)

"Allah" and "Jesus" are the two religious (divine) references in the song used to spiritualize the covertly nuanced Internet fraud (Yahoo) which its higher alternative is to "do blood money" (Yahoo-Plus). The nuanced meaning is: if Yahoo does not pay after praying to Jesus/Allah, Yahoo-Plus would be the resort. While "Allah" is to appeal to the Muslims, "Jesus" is to the Christians, attesting to the ecumenical and inclusive approaches adopted by Nigerian hip-hop artists, linguistically and religiously, to promote targeted contents. There are other Nigerian hip-hop songs with nuances of criminality masked in spiritualization such as Naira Marley's Soapy where he tied being a thief and not getting caught to prayerfulness.

\section{Contentions, contestations and convolutions}

Since the beginning of this century, numerous Nigerians have tried to criticize and discountenance those popular songs that they consider their themes and contents vicious. Particularly, the advent of social media platforms like Facebook, Twitter, and Instagram in Nigeria - from around 2008 when many Nigerians began to sign up to them - has equally given more Nigerians access to consuming and expressing various opinions on the contents of contemporary Nigerian popular music. The pool of these various contributions and opinions, including those of the musicians, has revealed thoughts and leanings that are not only contended but hotly contested. Amidst these contentions and contestations, it could be perceived that the contemporary Nigerian hip-hop artists take advantage of the chaos to engage in crafty manipulations that help to produce societal convolutions. To explain further, Nigerian hip-hop songs and raps, produced since the $21^{\text {st }}$ century, which carry personally and publicly offensive nuances have always had several Nigerians (including the musicians themselves) who are either strongly for or against them, as well as those who try to contest both sides. 
Within the context of this article, no Nigerian popular music artist has ever admitted to promoting or endorsing crime, criminality, or violence. Usually, the reactions by the artists are one of denial and, sometimes, defusing or crossconfrontation. For instance, Olamide and Lil Kesh are heavily accused by Nigerians of glamorizing Internet fraud and other publicly offensive contents but they deny having such intent saying "[it] is for the 3rd party to have a glimpse into the current state of youths in our society" (Ohunyon, 2018). On another hand, Olamide contradicts the same intent leaning on another self-serving one that brings him closer to admitting the accusations. In his words, he is reported to have said: "if I do amazing songs it won't trend" (Afolayan, 2018). To this excuse which contradicts the former, some Nigerians rise in defense (in the comment sections of the various online news report and on the musicians' social media handles) citing reasons of young musicians not being sufficiently accepted and financially patronized in Nigeria when they make "good music" (Afolayan, 2018). In defiance, other Nigerians flatly reject the reasons. Consequently, Nigerians are divided into contenders and contesters of notions, meanings, and reasons of/for 'good' and 'bad' contents in Nigerian hip-hop songs and raps. The conflict helps to boost the contended songs' popularities making them trend and gain more attention. On the other hand, there are some Nigerian artists who themselves try to rationalize and provide seemingly 'balanced' insights to mediate the controversy. For instance, Weflo, a Nigerian hip-hop artist laments that it is very difficult, if not impossible, for an upcoming artist to succeed in the Nigerian music industry based on the person's talent and hard work. On the entire difficult process in the Nigerian music industry and how it compels some artists into joining Internet fraud or promoting it, Weflo summarily reveals that financial exigencies constrain upcoming artistes into aligning themselves with the Yahoo business and concludes that "It's not in my place to judge anyone, because we are all responsible for our actions at the end of the day". 9

Weflo's rather diplomatic position is challenged by some other artists like Simi who speaks against Internet fraud and condemns any reasons for its justification or rationalization by her colleagues. As expected, Simi comes under attack by her colleagues who accuse her of not speaking out against Nigerian politicians who engage in stealing public funds thereby making it possible for teeming jobless Nigerian youths to find solace in Yahoo-yahoo ${ }^{10}$. In 2010, older musicians released a song, Maga No Need Pay - sponsored by Microsoft Internet Safety Security and Privacy Initiative for Nigeria (MISSPIN) - strongly discouraging Internet fraud as well as its promotion by their colleagues in the music industry (Bez Idakula, 2011). Like Simi, they also earned ridicule from their pro-Yahoo colleagues and fans at the time.

Going by these developments, one is persuaded to ask: what emboldens more Nigerian youths (including musicians and fans), in the last ten years and now, to not only engage in Internet fraud and its promotion but attack anyone who condemns their acts? To what end and extent are they bent on compelling the public to accept their activities and the messages spread by pro-Yahoo hip-hop artistes? Those are the convolutions that have emerged from what started as contentions and contestations on a criminal development, and Ibe-Anyanwu (2019) admits that it is a "never-ending yahoo debate" which is "gaining bolder acceptance" going forward. He gives a clue of the emboldening thought that encourages the pro-Yahoo musicians and fans citing that the controversial Naira Marley "has been defensive of Internet fraud which

9 Weflo, in 2018, spoke in an interview to Information Nigeria, a Nigerian online news agency, www.informationng.com/2018/08/why-a-lot-of-nigerian-artistes-are-into-yahoo-yahoo-singer-weflo.html

10 Nigerian pro-Yahoo fans and artistes attack Simi for speaking against Yahoo-yahoo. Retrieved from https://www.happenings.com.ng/latest/2019/04/08/overzealous-fan-comes-for-simi-accuses-husband-of-supporting-yahooboys\# 
he claims is a form repatriation for slavery, giving the controversy a new intellectual station". This "payback" for the transatlantic slave trade suffered by Nigerian ancestors in the hands of European and American slave merchants "from the middle of the $15^{\text {th }}$ century until the end of the $19^{\text {th }}$ century" (Adi, 2012) is also boldly approved and amplified by random youths in Nigerian cities while others disapprove of it, revealing not only a gulf between the two contenders but a convoluted status of the issue ${ }^{11}$. There is also an internal curve to the 'payback argument' which is rationalized as getting back at Nigeria's secluded and apathetic politicians for their long years of neglect and poor governance leading to mass impoverishment and depression. Ibe-Anyanwu (2019) further contends that Yahoo boys' popularity is exacerbated by Nigeria's worsening economic situation as many now tend to say that "the politician is your problem not the Yahoo guy".

Again, there is the curve which we have chosen to identify as the "jungle curve". The jungle curve shows that Yahoo boys do not choose victims as they claim; they also engage in a jungle-style preying on fellow Nigerians, whether rich or poor. This does not exclude family members and private organizations. Indeed, they prey on any available person or establishment to sustain their greed. ${ }^{12}$ These convolutions give rise to a more emboldened pro-yahoo divide that includes the Internet fraudsters (Yahoo boys) themselves, the hip-hop musicians, and the fans. Consequently, Nigeria and Nigerians suffer international disrepute and there is massive urge for quick wealth among the Nigerian male youths as well as mass arrest and incarceration of convicted Nigerian young men across the world ${ }^{13}$. While the Nigerian government fights Internet fraud, it is quite curious that, in recent times, the fraudsters (Yahoo boys) reportedly fund some music productions and artists devoted to nuanced promotion/glamorization of Yahoo or giving them [the Yahoo boys] subtle recognition in their music ${ }^{14}$. This lends credence to Weflo's earlier submission on how difficult it is for upcoming artists to succeed in the Nigerian music industry and the desperation to engage in Internet fraud and other things to raise funds which it breeds. Additionally, some Yahoo boys are reportedly the founders and owners of most "new generation record labels"15, earning them the status of economic imperialists in the music industry who determine the songs that sell and are forced to hit the public ears. Also, Chinweuba Odo, a music producer who has been quoted earlier, corroborates that "the record label owners determine what the artist sings. For example, I have a record label and I tell my artist what to sing. You can then imagine what producers who are pro-Yahoo compel their artists to do". ${ }^{16}$

Consequently, there is an exponential increase in Internet fraud acceptance and practice in the last decade among many Nigerian youths within the age bracket of 19-39. Arguing that hip-hop music lends itself to the representation and communication of resistance to lawfulness and good conduct, Phil Ford (2013) aptly states that "Hipness is not an idea, style or habit, but rather a stance towards the square, uptight, unfree world" (p.4). Ford's submission supports one of the important findings in this discourse which is: that the biggest and most effective medium for spreading and proselytizing

\footnotetext{
${ }^{11}$ Genius Radio TV. (2019, April 25). Are yahoo boys revenging for the slavery of the forefathers: Nigerians react to Naira Marley's statement. [Video file]. Retrieved from www.youtube.com/watch?v=dm50QFHAWEM

${ }^{12}$ Ibe-Anyanwu (2019): www.medium.com/@immanueljamesibeanyanwu/naira-marley-and-the-yahoo-debate41ed6b072e19

${ }^{13}$ Over 70 Nigerian young men were recently arrested by America's Federal Bureau of Investigation (FBI) for defrauding America's individuals and organizations to the tune of $\$ 400$ million. Retrieved August 23, 2019 https://guardian.ng/news/u-s-names-80-nigerians-in-massive-fraud-investigation-two-arrested/.

${ }^{14} \mathrm{~A}$ Nigerian rapper, N6 insists that it is impossible to "separate entertainment/entertainers from illegal money". Retrieved August 28, 2019 https://www.lindaikejisblog.com/2017/7/you-cant-separate-entertainment-from-illegal-money-most-ofthe-highest-money-entertainers-make-is-from-people-with-illegal-money-rapper-n6-says.html.

${ }^{15}$ Nigerian hip-hop artist, D'Banj (Daniel Oyebanjo) remarks that "most of the new generation record labels are founded by yahoo boys". Retrieved August 28, 2019. https://www.nairaland.com/4376167/dbanj-yahoo-boys-own-most

${ }^{16}$ Personal communication, May 9, 2020
} 
Internet fraud (Yahoo-yahoo) in Nigeria and among Nigerian youths is the Nigerian hip-hop and rap. Using both genres, it is easier to encode and endorse pro-Yahoo and other criminal messages amidst robust rhythms, choreographies, instrumentations, and melodies.

\section{CONCLUSIONS}

So far, this article has been approached from general discussions on Nigerian popular music to tracing its roots of nuancing criminality and violence. Besides, we have analytically examined six selected Nigerian hip-hop songs (as well as the raps that accompanied them) produced between 2014 and 2019, focusing on the musical elements, texts, and themes that nuanced and endorsed criminality and/or violence in them. Mainly, these nuances discussed herein range from glamorization/valorization/promotion of Internet fraud (yahoo-yahoo), cyber-related crimes and money rituals (yahoo plus) to evasion of justice and its encouragement to open approval/recognition of violent persons of criminal backgrounds and to sexual violence towards young women. Of these nuances, the most dominant and consistent is that of cybercrime. We have also identified a few trends/developments that accompanied/accompany these nuances which we have designated as "extended hegemony", "symbolic simulation", and "spiritualization of criminal contents in contemporary Nigerian popular music." Also - and specifically_-we argue that the interaction between contemporary Nigerian hip-hop music and criminality/violence has given rise to a growing youth acceptance, practice, and defense of Internet fraud (yahoo-yahoo) as well as money rituals (yahoo plus) at an unprecedented rate since the inception of the $21^{\text {st }}$ century. Meanwhile, the Nigerian Broadcasting Corporation (NBC) has long lists of bans of ill-themed songs from Nigeria's airwaves but not from the social media ecosystem, making the bans less effective as many more Nigerian youths still subscribe to them (Eze, 2020). Consequently, Nigeria's financial crime agency (EFCC) seems overwhelmed by this explosion of Internet fraud cases making it call on the "greater attention" of Nigerians as well as asking Nigerians to collaborate with America's Federal Bureau of Investigation (FBI) in addressing it. ${ }^{17}$ Addressing properly this ugly trend in music industry will improve music production and engineering.

\section{ACKNOWLEDGEMENTS}

The researchers appreciate Dr Benedict Agbo for serving as the corresponding author for this research. All the research participants are very much appreciated for their active participation in the research.

\section{REFERENCES}

1. Achebe, C. (2012). There was a country. US: Penguin

2. Adeniyi, O. (2020). Nigeria: money ritual and the head hunters. Retrieved January 3, 2020, from https://allafrica.com/stories/202001020226.html

3. Adi, H. (2012). Africa and the transatlantic slave trade. Retrieved August 30, 2019, from http://www.bbc.co.uk/history/british/abolition/africa_article_01.shtml

4. AREO, MARGARET OLUGBEMISOLA. "Regbe-Regbe: Multidimensional Impact of Cloth and Colour in Ojude-Oba Festival." International Journal of Humanities and Social Sciences 5.5 (2016): 55-72.

\footnotetext{
${ }^{17}$ Nigeria's Economic and Financial Crime Commission (EFCC) boss, Ibrahim Magu called on Nigerians to pay more attention cyber-crime. Retrieved August 30, 2019. https://www.icirnigeria.org/efcc-chairman-advocates-greater-attentionto-cybercrime/
} 
5. Afolayan, K. (2018). If I do amazing songs it won't trend - Olamide defends his new song. Retrieved August 22, 2019 from https://www.naijaloaded.com.ng/entertainment/if-i-do-amazing-songs-it-wont-trend-olamide-defends-his-new-song

6. Ahmed, Ayesha Sultana, and A. Mary Swarnalatha. "Review on Usage of New Media Among Undergraduate Students." International Journal of Computer Science and Engineering (IJCSE) 7.1: 1-8.

7. Akinyoade, A. (2019). Naira Marley breaks silence on his arrest. Retrieved August 19, 2019, from https://guardian.ng/life/naira-marley-says-he-has-been-arrested-24-times-in-england/

8. ARORA, HARCHARAN SINGH. "THESPIAN TALENT AND DRAMATIC PERFORMANCE IN SHAKESPEAREAN ERA: AN OVERVIEW." International Journal of English and Literature (IJEL) 8.3, Jun 2018, 31-38

9. Augoye, J. (2018). Olamide justifies promoting money rituals in 'logo benz'. Retrieved August 12, 2019, from https://www.premiumtimesng.com/entertainment/music/302305-olamide-justifies-promoting-money-rituals-in-logo-benz.html

10. Augoye, J (2019). EFCC arrests Nigerian musician, Naira Marley. Retrieved August 19, 2019, from https://www.premiumtimesng.com/news/top-news/329282-breaking-efcc-arrests-nigerian-musician-naira-marley.html

11. Aworinde, T. (2018). Olamide, Lil Kesh's logo benz criticized for promoting money ritual. Retrieved August 29, 2019 from www.punchng.com/olamide-lil-keshs-logo-benz-criticised-for-promoting-money-ritual/

12. Christopher, N. (2012). An assessment of Nigeria urban youth music. Khazar Journal of Humanities and Social Sciences, $65-$ 79. Retrieved July 17, 2020. http://jhss-khazar.org/wpcontent/uploads/2012/05/04-CHRISTOPHER-NM1.pdf

13. Christopher, N. (2013). Violence and popular music in Nigeria. NCUE Journal of Humanities 8 (1): 135-148

14. City Population. (2016). Oshodi-Isolo local government area in Nigeria. Retrieved August 19, 2019, from https://www.citypopulation.de/php/nigeria-admin.php?adm2id=NGA025018

15. Edet, Itari Paul, Beshel Cecilia Akpan, and Okeme Isaac. "Indigenous communication media and utilization of development information in rural communities of south-south Nigeria." International Journal of English and Literature 5.1 (2015): 85-96.

16. Ehbomele, E. (2011a). Resign now, Tinubu tells Lagos NURTW boss. Retrieved July 27, 2019, from https://www.pmnewsnigeria.com/2011/05/07/resign-now-tinubu-tells-lagos-nurtw-boss/

17. Ehbomele, E. \& Ayodeji. D. (2011b) N7.4B probe: NURTW crisis deepens, Olohunwa seeks Tinubu's assistance. Retrieved July 27, 2019, from https://www.pmnewsnigeria.com/2011/05/09/n7-4b-probe-nurtw-crisis-deepens-olohunwa-seekstinubu\%e2\%80\%99s-assistancel

18. Eze, S. (2020). Sexism and power play in the Nigerian contemporary hip hop culture: the music of Wizkid, Contemporary Music Review, https://doi.org/10.1080/07494467.2020.1753479

19. Ezeamalu, B. (2017). How Nigerian churches are encouraging corruption - Obasanjo. August 19, 2019, from https://www.premiumtimesng.com/news/headlines/228306-nigerian-churches-encouraging-corruption-obasanjo.html

20. Falola, T. (1998). Violence in Nigeria: the crisis of religious politics and secular ideologies. Rochester, NY: University of Rochester.

21. Folarin, S. (2019). Lust for money and yahoo-plus mania in Nigeria. Retrieved August 19, 2019, from https://punchng.com/lust-for-money-and-yahoo-plus-mania-in-nigeria/

22. Ford, P. (2013). Dig: sound and music in hip culture. New York: Oxford University Press.

23. Ibe-Anyanwu, I-J. (2019). Naira Marley and the yahoo debate. Retrieved August 27, 2019, from https://medium.com/@immanueljamesibeanyanwu/naira-marley-and-the-yahoo-debate-41ed6b072e19 
24. Ige, O. (2019). Popular cleric reveals why yahoo boys use female pants for money rituals. Retrieved August 19, 2019, from https://www.concisenews.global/2019/01/31/popular-cleric-reveals-why-yahoo-boys-use-female-pants-for-money-rituals/

25. Johnson, B \& Cloonan, M. (2009). Dark side of the tune: popular music and violence. England \& US: Ashgate Publishing Limited.

26. Kahn-Harris, K. (2004). Aesthetics of hate music. Institute of Jewish Policy. Retrieved July 27, 2019, from https://archive.jpr.org.uk/download?id=2235

27. Lazarus, S. (2018). Birds of a feather flock together: the Nigerian cyber fraudsters (yahoo boys) and hip-hop artists. Criminology, Criminal Justice, Law and Society, 19; 2, 63-80.

28. Marshall, J. (2018). The world's most committed Christians live in Africa, Latin America - and the U.S. Retrieved August 22, 2019, from https://www.pewresearch.org/fact-tank/2018/08/22/the-worlds-most-committed-christians-live-in-africa-latinamerica-and-the-u-s/

29. Nworah, U. (2005). Igwe Nebolisa dead? Retrieved July 26, 2019 http://nigeriavillagesquare.com/forum/threads/igwenebolisa-dead.2304/?fbclid=IwAR1EBMQByLT3c9VQToZNmQVF_Kydqo3tyMjSMuxG-qAY98x-qPkxcpGFDgQ

30. OSAZEE-ODIA, OGHOGHO UYI. "PATTERNS OF YOUNG ADULTS'PERCEPTIONS AND USAGE OF MOBILE PHONE: THE CASE OF UNIVERSITY STUDENTS IN NIGERIA." International Journal of Communication and Media Studies (IJCMS) 7.2, Jun 2017, 15- 34

31. Odunsi, W. (2019). Why we arrested Naira Marley, Zlatan Ibile, Rahman Jago, others - EFCC gives details. Retrieved August 19, 2019, from https://dailypost.ng/2019/05/10/breaking-arrested-naira-marley-zlatan-ibile-rahman-jago-others-efcc-givesdetails-photos/

32. Ohunyon, E. (2018). Like Lil Kesh Olamide responds to criticisms over lyrics on 'Logo Benz'. Retrieved August 19, 2019 , from https://www.pulse.ng/entertainment/music/olamide-responds-to-criticisms-over-lyrics-on-logo-benz/v0ylpqp

33. Ohwojeheri, E. A. (2014). Olamide's story for the gods: a Nigerian song recommending rape? Retrieved July 26, 2019, from http://saharareporters.com/2014/11/27/olamides-story-gods-nigerian-song-recommending-rape-eseoghene-al-faruqohwojeheri

34. Olugbile, F. (2020). Naira Marley and the 'Marlian' counter-culture. Retrieved January 31, 2020, from https://businessday.ng/columnist/article/naira-marley-and-the-marlian-counter-culture/

35. Onanuga, P \& Onanuga, A. (2020). Violence, sexuality and youth linguistic behaviour: an exploration of contemporary Nigerian youth music. Contemporary Music Review, https://doi.org/10.1080/07494467.2020.1753478

36. Onwuegbuna, I. E. (2016). Operational arrangement of rhythm in Nigerian reggae songs. Nsukka Journal of the Humanities, 24: $2,106-120$.

37. Pierre, A. (2019). The ones: Naira Marley and Zlatan's “am I a yahoo boy”. Retrieved August 19, 2019, from https://pitchfork.com/levels/naira-marley-and-zlatan-am-i-a-yahoo-boy/

38. Sahara Reporters (2019). Exclusive: Naira Marley was a wanted criminal in the UK in 2014. Retrieved August 19, 2019, from http://saharareporters.com/2019/05/22/exclusive-naira-marley-was-wanted-criminal-uk-2014

39. Sylvanus, E. P. (2018). Popular music and genre in the mainstream Nollywood. Journal of Popular Music Studies, 30: 3 , 99114.

40. Tayo, A. O. (2019). How Internet fraud has taken over Nigerian music: $24^{\text {th }}$ April, 2019. Retrieved July 28, 2019, from https://www.pulse.ng/entertainment/music/naira-marley-internet-fraud-and-nigerian-music/gk7j1vj 
41. Udodiong, I. (2019). Nigerians named the most prayerful people in the world-95\% say they pray daily. Retrieved August 22, 2019, from https://www.pulse.ng/bi/lifestyle/nigerians-named-the-most-prayerful-people-in-the-world-95-say-they-praydaily/psnle0e

42. Ugbodaga, K. (2015a). Oshodi crisis: MC Oluomo snubs police. Retrieved July 27, 2019, from https://www.pmnewsnigeria.com/2015/03/02/oshodi-crisis-mc-oluomo-snubs-police/

43. Ugbodaga, K. (2015b). Oshodi mayhem: police arraign 18, orders Oluomo to surrender himself. Retrieved July 27, 2019, from https://www.pmnewsnigeria.com/2015/02/26/oshodi-mayhem-police-arraign-18-orders-oluomo-to-surrender-himself/

44. Wahab, B. (2019). 'I've been arrested 124 times in England', Naira Marley speaks after his arrest. Retrieved August 19, 2019 , from https://www.pulse.ng/entertainment/celebrities/ive-been-arrested-124-times-in-england-naira-marley-speaks-after-hisarrest/veyzhbf

45. Bez Idakula (2011, May 17). Maga no need pay - Banky W, Bez, Cobhams, MI, Modele, Omawumi, rooftop MCs, wordsmith.flv [Video file]. Retrieved from www.youtube.com/watch? $=q B b D 8 d 3 c u G 8$

46. Chinko Ekun. (2018, October 4). Able God ft. Lil Kesh $\times$ Zlatan Ibile (official video) [Video file]. Retrieved from https://www.youtube.com/watch? $v=r v S y I q Z S z H w$

47. Genius TV Radio. (2018, December 29). Yahoo boys now use girls' pants and pads for money rituals: Nigerians react [Video file]. Retrieved from https://www.youtube.com/watch? $=m v 4 \mathrm{krwL} 1 \mathrm{joA}$

48. KeshVEVO (2018, December 19). Lil Kesh, Olamide - logo benz (audio) [Video file]. Retrieved from https://www.youtube.com/watch?v=22BRl_SqXro

49. Naira Marley. (2018, November 9). Japa (official video) [Video file]. Retrieved from https://www.youtube.com/watch?v=HOok_o_zLCM

50. Naira Marley. (2019, May 9). Naira Marley $\times$ Zlatan - am I a yahoo boy? [Video file]. Retrieved from https://www.youtube.com/watch?v=vvBZk4a871I

51. Olamide Baddosneh. (2014, July 29). Olamide - story for the gods (official video) [Video file]. Retrieved from https://www.youtube.com/watch?v=lPS3DDOWcgg

52. Teni Entertainer. (2018, October 19). Teni - case (official video) [Video file]. Retrieved from https://www.youtube.com/watch? $v=h Y x 5 u k r_{-} Y W w$ 